\title{
Characterization of Pathogenic Races of Fusarium oxysporum f. sp. melonis Causing Fusarium Wilt of Melon in New York
}

\author{
T. L. Zuniga, Graduate Research Assistant, and T. A. Zitter, Professor, Department of Plant Pathology, Cornell \\ University, Ithaca, NY 14853; T. R. Gordon, Associate Professor, D. T. Schroeder, Graduate Research Assistant, \\ and D. Okamoto, Staff Research Associate, Department of Environmental Science Policy and Management, Uni- \\ versity of California, Berkeley 94720
}

\begin{abstract}
Zuniga, T. L., Zitter, T. A., Gordon, T. R., Schroeder, D. T., and Okamoto, D. 1977. Characterization of pathogenic races of Fusarium oxysporum f. sp. melonis causing Fusarium wilt of melon in New York. Plant Dis. 81:592-596.

Forty-six isolates of Fusarium oxysporum f. sp. melonis obtained from soil samples throughout melon-producing areas in New York State were identified on the basis of pathogenicity and colony morphology. Physiological races 1 and 2 were identified by their reaction on a set of differential melon cultivars. Race 1 was widely distributed, occurring in six of the seven New York counties surveyed. Twenty-seven of the 28 race 1 isolates were associated with vegetative compatibility group (VCG) 0134, whereas one was incompatible with all known VCGs of $F$. oxysporum f. sp. melonis. Twelve out of 18 race 2 isolates were associated with VCG 0131, and occurred in four counties in eastern and western New York. Five isolates of race 2, associated with VCG 0130, were recovered from a farm in Washington County, as was a single race 2 isolate which was incompatible with all known VCGs of $F$. oxysporum f. sp. melonis. Restriction fragment length polymorphisms in the nuclear DNA revealed variability among the isolates examined, but race 1/VCG 0134 isolates from New York and Maryland were identical or nearly so, as were race 2/VCG 0131 isolates from the two states. These findings suggest a close relationship between the populations of F. oxysporum f. sp. melonis in New York and Maryland. Race 2 isolates were more virulent than race 1 isolates, based on the number of days to first symptoms and death of melon seedlings.
\end{abstract}

Additional keywords: cantaloupe, Cucumis melo, muskmelon

Fusarium wilt of melon (Cucumis melo L.) is caused by the fungus Fusarium oxysporum Schlechtend.:Fr. f. sp. melonis W. C. Snyder \& H. N. Hans. Identification to forma specialis is dependent upon a pathogenicity assay on a susceptible melon cultivar such as Top Mark. Of the seven formae speciales attacking cucurbits, F. oxysporum f. sp. melonis is one of the most important on a worldwide scale (9).

Four races of Fusarium wilt infecting melons have been designated $0,1,2$, and 1,2 (18). Two genes for resistance, Fom 1 and Fom 2, are currently used to identify races of the pathogen (22). Race 2 predominates in the United States, and was the only race known in North America until 1985, when race 1 was discovered in Maryland (3). Race 0 was found in Texas in 1986 (13). More recently, race 1 was identified in New York (23) and race 1,2 in Maryland (1).

Corresponding author: T. A. Zitter

E-mail: taz1@cornell.edu

Accepted for publication 14 February 1997.

Publication no. D-1997-0422-09R

(C) 1997 The American Phytopathological Society
Once introduced into a field, $F$. oxysporum f. sp. melonis can remain indefinitely, even after rotation to nonsusceptible crops (4). The fungus survives as chlamydospores, and is capable of colonizing crop residue and roots of most crops likely to be grown in rotation with melon (4). It can enter the host through root tips, primarily in the area of elongation, and is aided by wounding (14). As a result of the persistence of the pathogen in the soil, the disease is best controlled with cultivars that carry multiple resistance $(11,16,21)$.

Currently, eight vegetative compatibility groups (VCGs) are recognized in the forma specialis melonis worldwide. Some VCGs are associated with one or more physiological races (6); in Europe, all four races of $F$. oxysporum f. sp. melonis have been associated with VCG 0134. Because the recently identified isolates of races 1 and 1,2 in North America were associated with VCG 0134, which was previously unknown in North America, it seems likely these new races were introduced from Europe, where VCG 0134 is common (7).

The principal objective of this project was to identify the race or races of $F$. oxysporum f. sp. melonis in the melon-producing areas of New York state. Because the survey revealed the occurrence of race 1 , not previously known in New York State, we sought to make a preliminary assessment of the population structure of $F$. oxysporum f. sp. melonis to gain a better understanding of the origin of this new race in the state. A portion of this study has previously been reported $(19,24)$.

\section{MATERIALS AND METHODS}

Soil survey and isolation of $F$. oxysporum. Three hundred ninety soil samples were collected in June and July 1993 from three geographical regions of New York State; eastern (Columbia, Rensselaer, Schoharie, and Washington counties), central (Onondaga County), and western (Erie and Niagara counties) (Fig. 1). For each sample, approximately $500 \mathrm{~g}$ of soil was collected at a depth of 10 to $20 \mathrm{~cm}$ in an area of $1 \mathrm{~m}^{2}$ using a soil-sampling probe. The probe was dipped in alcohol and flamed after each sampling to avoid contamination. Sampling sites were areas where melons were grown during 1991 to 1993; 10 to 20 samples were taken per field. A repeating $\mathrm{W}$-shaped pattern was used to adequately cover a field.

Each soil sample was assayed by transplanting 10-day-old seedlings of the susceptible melon cv. Top Mark into 7.5-cm clay pots. Plants were maintained in a greenhouse at 27 to $29^{\circ} \mathrm{C}$, day, and 18 to $24^{\circ} \mathrm{C}$, night. Seedlings were observed daily for symptom development. Those exhibiting yellowing or wilting were uprooted and surface-disinfested with a 1:10 dilution of Clorox for $1 \mathrm{~min}$. Individual stem and root pieces were plated on Komada's medium (10) and incubated for 7 days. Individual colonies resembling $F$. oxysporum were transferred to potato dextrose agar (PDA) plates, single-spored, and transferred to PDA slants for further identification to species and forma specialis. Final identification of $F$. oxysporum to species was based on colony morphology (cottony white aerial mycelium with purplish pigmentation) on PDA and morphology of micro- and macroconidia and chlamydospores on carnation leaf agar (15). For long-term storage, the isolates were stored as filter paper cultures (2).

Pathogenicity and race determination. Each recovered $F$. oxysporum isolate was used to inoculate two Top Mark seedlings to establish pathogenicity and to identify the forma specialis melonis. Fungal isolates were grown on PDA plates for 7 to 8 
days at room temperature under two $20 \mathrm{~W}$ fluorescent lights for $14 \mathrm{~h}$. Conidial suspensions were standardized to $1 \times 10^{6}$ spores $/ \mathrm{ml}$. Seedlings were inoculated by dipping the roots in the inoculum suspension for $1 \mathrm{~min}$. Seedlings potted in $10-\mathrm{cm}$ clay pots with steamed potting mix (1 part each soil:sand:peat moss:compost) were held in a greenhouse at 27 to $29^{\circ} \mathrm{C}$, day, and 18 to $24^{\circ} \mathrm{C}$, night. Inoculated seedlings were observed daily for symptom development over a 4-week period. Race determination was made by observing symptom development on two inoculated seedlings of the differential cultivars Top Mark, Doublon (or Top Mark FR), and CM17$187(18,22)$. The test was performed under the same environmental conditions previously described.

Comparison of virulence for $F$. oxysporum f. sp. melonis races 1 and 2 . Fifteen isolates each of $F$. oxysporum f. sp. melonis races 1 and 2 were used to inoculate 5 10-day-old seedlings of Top Mark to determine differences in virulence between the two pathotypes. The isolates chosen for each race were randomly selected to represent the three sampled geographical regions of the state. Procedures for inoculum preparation, concentration, and inoculation were the same as previously described. The environment chamber set at $23^{\circ} \mathrm{C}$, day, and $18^{\circ} \mathrm{C}$, night, with $14 \mathrm{~h}$ fluorescent light. Isolates were selected to represent a statewide distribution of $F$. oxysporum $\mathrm{f}$. sp. melonis. Differences in virulence were measured by recording the number of days to first symptoms (DTFS) and the number of days to death (DTD). Readings were taken daily for a period of two weeks. Calculations of DTFS and DTD were made when $50 \%$ of the seedlings showed symptoms and died, respectively. Means of these two parameters for both races were compared using a $t$ test (12). experiment was conducted in a controlled

Vegetative compatibility groups. $\mathrm{Ni}$ trate nonutilizing mutants (nits) were obtained from the 46 soil isolates of $F$. oxysporum f. sp. melonis as described by Gordon and Okamoto (5). nits from each isolate were paired on a minimal medium (17) with complementary nits representing previously characterized VCGs of $F$. $o x$ ysporum f. sp. melonis (8). A pairing reaction was scored as positive when complementing nits produced wild type growth (aerial mycelium) along the line of contact.

Restriction fragment length polymorphisms in nuclear DNA of races 1 and 2. To obtain the probe used to visualize restriction fragments, nuclear DNA of $F$. oxysporum f. sp. melonis isolate Pt-1 was separated from other fractions by cesium chloride centrifugation. Fragments resulting from digestion of the nuclear DNA with $E c o$ R 1 were cloned into a pUC vector using cloning kit 1013 084, as per the manufacturer's instructions (Boehringer Mannheim Biochemicals, Indianapolis, IN). A $6.0 \mathrm{~kb}$-fragment thus obtained, designated as pnFOM-9, was found to hybridize with multiple bands in restriction digests of F. oxysporum f. sp. melonis isolates (20).

Each isolate to be examined was grown in liquid culture, mycelium was harvested and lyophilized, and DNA was extracted as described by Appel and Gordon (1). Total DNA was digested for $1 \mathrm{~h}$ with EcoR1 and treated with RNase for an additional half hour. Fragments were separated electrophoretically in $1 \%$ agarose at a current of $20 \mathrm{Ma}$ for $18 \mathrm{~h}$. Agarose gels were blotted and stored under vacuum at room temperature. Bands were visualized using a DIG DNA labeling and detection kit (Genius 1) according to the manufacturer's instructions (Boehringer Mannheim Biochemicals). Similarities among isolates of F. oxysporum f. sp. melonis were assessed by determining the extent to which the

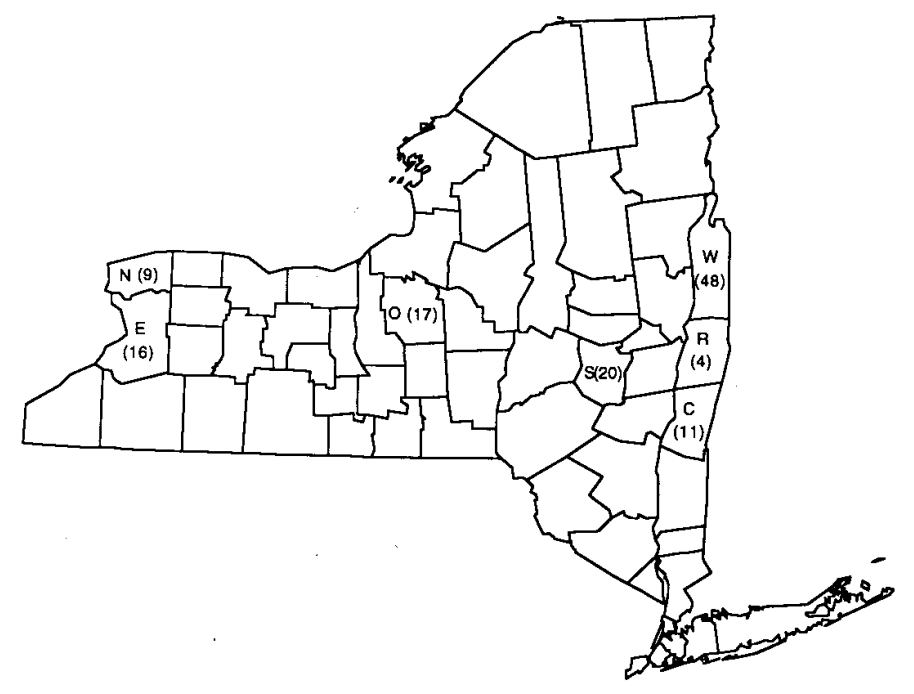

Fig. 1. Location and number of Fusarium oxysporum isolates collected in New York State in 1993, where $\mathrm{E}=$ Erie, $\mathrm{N}=$ Niagara, $\mathrm{O}=$ Onondaga, $\mathrm{R}=$ Rensselaer, $\mathrm{S}=$ Schoharie, and $\mathrm{W}=$ Washington. restriction fragments of the same mobility, which hybridized to pnFOM-9, were shared.

\section{RESULTS}

Race survey of $F$. oxysporum f. sp. melonis from soil. One hundred twentyfive isolates of $F$. oxysporum were recovered from the 390 soil samples collected (Fig. 1), and 46 were identified as F. oxysporum f. sp. melonis (Table 1). Twentyeight of the isolates were identified as race 1 , and 18 were identified as race 2 . A majority of the isolates (39 of 46) came from eastern New York; where race 1 was recovered from Washington, Columbia, and Schoharie counties (23 isolates) and race 2 was recovered from Washington, Columbia, Rensselaer and Schoharie counties (16 isolates) (Fig. 1). Three isolates of race 1 were recovered from Onondaga County in central New York, and one each from Erie and Niagara counties in western New York. Two isolates of race 2 were also identified in Erie County.

Four of the 28 race 1 isolates were recovered from a field in Washington County that had not grown melons since 1991, 17 from fields that had been planted to melons in 1992, and the remaining 7 isolates from fields where melons were growing during the 1993 soil sampling period (Table 1). Five of the 18 race 2 isolates were recovered from fields that produced melons in 1992, and 13 from fields cropped to melons in 1993. On four of the nine farms from which $F$. oxysporum f. sp. melonis was recovered, both race 1 and 2 were present, representing four different counties in eastern and western New York (Table 1).

Race 1 and 2 virulence study. Races 1 and 2 were statistically different $(P=0.05)$ with respect to DTFS and DTD. Seedlings inoculated with 15 race 2 isolates showed symptoms an average 1.3 days sooner than the seedlings inoculated with 15 race 1 isolates (Table 2). The same plants inoculated with race 2 died an average 1 day sooner than those inoculated with race-1 isolates.

Vegetative compatibility groups. Twelve race 2 isolates were associated with VCG 0131, 10 of which were from eastern New York (Columbia, Rensselaer, and Schoharie counties); the remaining 2 isolates were from western New York (Erie County) (Table 1). Five race 2 isolates were associated with VCG 0130, which was previously known only from California. All 5 isolates in VCG 0130 were isolated from one field in Washington county where melons were produced in 1992 and 1993. The remaining race 2 isolate was paired with tester strains representing all other known $F$. oxysporum f. sp. melonis VCGs $(7,8)$ and was not compatible with any of them.

Twenty-seven race 1 isolates were associated with VCG 0134, including 2 (isolates 
84 and 105 in Table 1) that were not compatible with the original tester strains but did pair with other isolates associated with VCG 0134. Twenty-three of the 27 race 1 isolates associated with VCG 0134 were from eastern New York (Columbia, Schoharie, and Washington counties), 2 were from central New York (Onondaga County), and 2 were from western New York (Erie and Niagara counties). A single race 1 isolate was not compatible with any $F$. oxysporum f. sp. melonis tester strains.

Restriction fragment length polymorphisms in nuclear DNA of races 1 and 2. Variation in nuclear DNA, based on restriction fragment length polymorphisms (RFLPs) revealed by a multi-locus probe, was characterized for 19 isolates (Table 3). Four RFLP patterns were evident among the 19 isolates (Fig. 2). Ten VCG 0134/race 1 isolates, 8 from New York and 2 from Maryland, were associated with pattern A (Fig. 2). Eight isolates from New York, including 84 and 105, were compatible with some but not all other 0134 isolates. One 0134/race 1 isolate from New York had a banding pattern very similar to A, sharing all but two of the major bands; this pattern was designated A1. Five 0131/race 2 isolates, 3 from New York and 2 from Maryland, were associated with pattern C (Fig. 2). Three 0130/race 2 isolates were associated with pattern $\mathrm{B}$, which included several prominent bands not seen in the 0131/race 2 isolates.

\section{DISCUSSION}

The presence of $F$. oxysporum f. sp. melonis races 1 and 2 in New York has

Table 1. Fusarium oxysporum f. sp. melonis races recovered from 1993 soil samples, the year planted to melons, the vegetative compatibility group (VCG), and location and county in New York

\begin{tabular}{|c|c|c|c|c|c|}
\hline Isolate number & Location & County & Year in melon & Race & $\mathrm{VCG}^{2}$ \\
\hline 1 & Ransomville & $\mathrm{N}$ & 92 & 1 & 0134 \\
\hline 3 & Hudson & $\mathrm{C}$ & 93 & 2 & 0131 \\
\hline 9 & Phoenix & $\mathrm{O}$ & 93 & 1 & 0134 \\
\hline 11 & Hamburg & E & 93 & 2 & 0131 \\
\hline 26 & Greenwich & $\mathrm{W}$ & 92 & 1 & 0134 \\
\hline 27 & Greenwich & W & 92 & 1 & 0134 \\
\hline 33 & Hudson & $\mathrm{C}$ & 93 & 2 & 0131 \\
\hline 37 & E. Greenbush & $\mathrm{R}$ & 93 & 2 & 0131 \\
\hline 38 & Hudson & $\mathrm{C}$ & 93 & 2 & 0131 \\
\hline 40 & Greenwich & $\mathrm{W}$ & 91 & 1 & 0134 \\
\hline 44 & Middleburg & $\mathrm{S}$ & 92 & 1 & 0134 \\
\hline 55 & Middleburg & $\mathrm{S}$ & 93 & 1 & 0134 \\
\hline 59 & Middleburg & $\mathrm{S}$ & 92 & 1 & 0134 \\
\hline 60 & Schoharie & $\mathrm{S}$ & 92 & 1 & 0134 \\
\hline 61 & Hudson & $\mathrm{C}$ & 92 & 1 & 0134 \\
\hline 62 & Schoharie & S & 92 & 1 & 0134 \\
\hline 64 & Hudson & $\mathrm{C}$ & 93 & 2 & 0131 \\
\hline 65 & Phoenix & $\mathrm{O}$ & 93 & 1 & 0134 \\
\hline 67 & Middleburg & $\mathrm{S}$ & 92 & 2 & 0131 \\
\hline 69 & Hudson & $\mathrm{C}$ & 93 & 2 & 0131 \\
\hline 73 & Hudson & $\mathrm{C}$ & 92 & 1 & 0134 \\
\hline 75 & Hudson & $\mathrm{C}$ & 93 & 2 & 0131 \\
\hline 77 & Greenwich & W & 92 & 1 & 0134 \\
\hline 78 & Hudson & $\mathrm{C}$ & 92 & 1 & 0134 \\
\hline 80 & Eagle Bridge & W & 93 & 2 & 0130 \\
\hline 81 & Eagle Bridge & W & 93 & 2 & NA \\
\hline 82 & Eagle Bridge & W & 93 & 2 & 0130 \\
\hline 84 & Greenwich & W & 91 & 1 & 0134 \\
\hline 86 & Greenwich & W & 91 & 1 & 0134 \\
\hline 88 & Greenwich & $\mathrm{W}$ & 91 & 1 & 0134 \\
\hline 92 & Greenwich & W & 92 & 1 & 0134 \\
\hline 100 & Eagle Bridge & $\mathrm{W}$ & 92 & 2 & 0130 \\
\hline 101 & Eagle Bridge & W & 92 & 2 & 0130 \\
\hline 103 & Eagle Bridge & W & 92 & 2 & 0130 \\
\hline 105 & Eagle Bridge & $\mathrm{W}$ & 92 & 1 & 0134 \\
\hline 112 & Middleburg & $\mathrm{S}$ & 93 & 1 & 0134 \\
\hline 114 & Schoharie & $\mathrm{S}$ & 92 & 1 & 0134 \\
\hline 115 & E. Greenbush & $\mathrm{R}$ & 93 & 2 & 0131 \\
\hline 116 & Schoharie & $\mathrm{S}$ & 92 & 1 & 0134 \\
\hline 117 & Middleburg & $\mathrm{S}$ & 93 & 1 & 0134 \\
\hline 118 & Phoenix & $\mathrm{O}$ & 93 & 1 & 0134 \\
\hline 119 & Hudson & $\mathrm{C}$ & 92 & 2 & 0131 \\
\hline 122 & Schoharie & $\mathrm{S}$ & 92 & 1 & 0134 \\
\hline 123 & Hamburg & $\mathrm{E}$ & 93 & 2 & 0131 \\
\hline 125 & Hudson & $\mathrm{C}$ & 92 & 1 & NA \\
\hline 126 & Hamburg & $\mathrm{E}$ & 93 & 1 & 0134 \\
\hline
\end{tabular}

y $\mathrm{C}=$ Columbia, $\mathrm{E}=$ Erie, $\mathrm{N}=$ Niagara, $\mathrm{O}=$ Onondaga, $\mathrm{R}=$ Rensselaer, $\mathrm{S}=$ Schoharie, $\mathrm{W}=$ Washington.

z NA indicates the isolate was not assigned to a VCG because compatibility with testers representing known VCGs could not be demonstrated.

already been reported, based on a limited number of isolates (23). The present survey found race 1 to be more widely distributed than was originally thought, with the greatest frequency of occurrence in eastern New York $(86 \%)$ compared to central or western locations (7\% each). Race 1 was recovered from six of the seven counties surveyed; Rensselaer was the only county in eastern New York where race 1 was not found. Race 2, the most prevalent race in the United States, was also recovered in eastern and western New York, but it accounted for only 18 of the 46 isolates of $F$. oxysporum f. sp. melonis (39\%). Race 2 was recovered from all four eastern counties but only from Erie county in western New York.

The presence of race 1 is of particular importance because resistance to this race in eastern-type melons is present in only a few commercial cultivars, and they are only now being evaluated by growers for horticultural features. Many more cultivars with resistance to race 2 are available for the eastern markets.

We previously reported the recovery of race 1 from severely wilted plants in a field in Washington County in 1992 (23). The recovery of 4 race 1 isolates from a field not planted to melons since 1991 suggests it has been in New York at least since 1991. Race 1 was readily recovered from soil, accounting for $57 \%$ of the isolates obtained from fields cropped to melons in 1992 and for $29 \%$ of the isolates recovered from fields planted to melons in 1993. Currently, race 1 is responsible for heavy losses on the farm where this race was first detected, and the grower has shifted the majority of his acreage to rented land which is not infested.

Although race 1 is now widely established in New York and is readily recovered from soil, race 2 isolates produced symptoms and killed inoculated seedlings sooner than did race 1 isolates.

Race 1 of $F$. oxysporum f. sp. melonis was only recently discovered in New York, whereas race 2 has been recognized in this state since the 1930s (14). The appearance of a new pathotype indicates either a change in the local population (through

Table 2. Difference in virulence between 15 isolates each of races 1 and 2 of Fusarium oxysporum f. sp. melonis in growth chamber studies

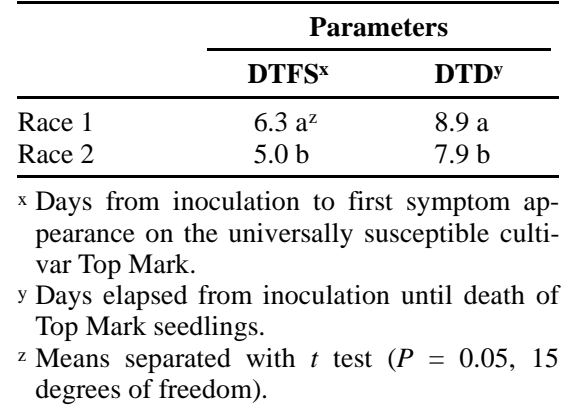




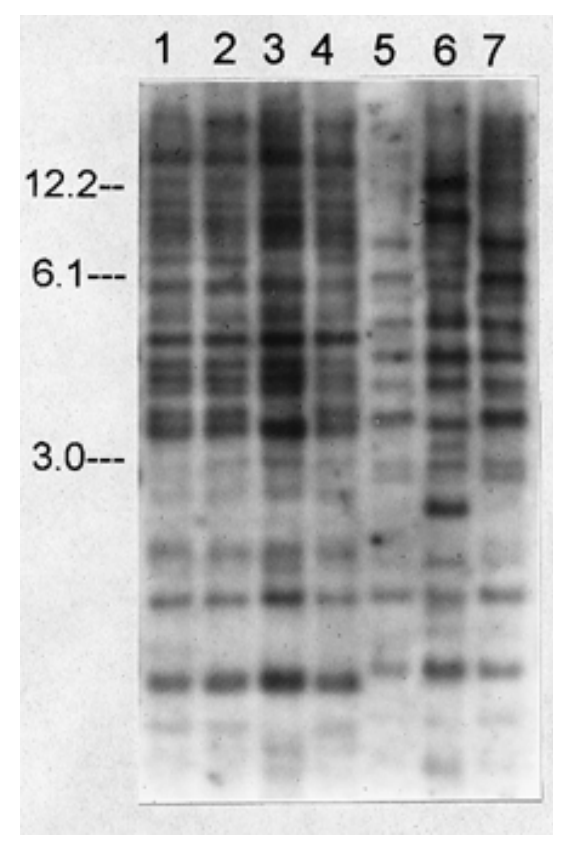

Fig. 2. An autoradiograph showing restriction fragment length polymorphisms in Fusarium oxysporum f. sp. melonis isolates from New York and Maryland. Total DNA from each isolate was cut with EcoR1 and probed with a repetitive element cloned from an isolate of $F$. oxysporum f. sp. melonis (see text for details). Isolates, from New York unless otherwise indicated, were assigned to lanes as follows, beginning with lane 1 : 88 , VCG 0134/race 1 (pattern A); 660A, VCG 0134/race 1 from Maryland, Jacobson and Gordon (7) (pattern A); 84, VCG 0134/race 1 (pattern A1); 105, VCG 0134/race 1 (pattern A); 123, VCG 0131/race 2 (pattern C); 82, VCG 0130/race 2 (pattern B); and B7-9S, VCG 0131/race 2 from Maryland, Appel and Gordon (1) (pattern C). Approximate size references, in kilobase pairs, are given to the left of lane 1 .

Table 3. Cross reference of Fusarium oxysporum f. sp. melonis isolates used for restriction fragment length polymorphism analysis

\begin{tabular}{lrlccc}
\hline Isolate & County & Region & Race & RFLP pattern $^{\mathbf{w}}$ & VCG $^{\mathbf{x}}$ \\
\hline 59 & Schoharie & Eastern NY & 1 & $\mathrm{~A}$ & 0134 \\
60 & Schoharie & Eastern NY & 1 & $\mathrm{~A}$ & 0134 \\
82 & Washington & Eastern NY & 2 & $\mathrm{~B}$ & 0130 \\
84 & Washington & Eastern NY & 1 & $\mathrm{~A} 1$ & 0134 \\
88 & Washington & Eastern NY & 1 & $\mathrm{~A}$ & 0134 \\
100 & Washington & Eastern NY & 2 & $\mathrm{~B}$ & 0130 \\
103 & Washington & Eastern NY & 2 & $\mathrm{~B}$ & 0130 \\
105 & Washington & Eastern NY & 1 & $\mathrm{~A}$ & 0134 \\
9 & Onondaga & Central NY & 1 & $\mathrm{~A}$ & 0134 \\
118 & Onondaga & Central NY & 1 & $\mathrm{~A}$ & 0134 \\
126 & Erie & Western NY & 1 & $\mathrm{~A}$ & 0134 \\
1 & Niagara & Western NY & 1 & $\mathrm{~A}$ & 0134 \\
11 & Erie & Western NY & 2 & $\mathrm{C}$ & 0131 \\
123 & Erie & Western NY & 2 & $\mathrm{C}$ & 0131 \\
MC1-1S $^{\mathrm{y}}$ & Caroline & Maryland & 1 & $\mathrm{~A}$ & 0134 \\
B3-3S & Wicomico & Maryland & 2 & $\mathrm{C}$ & 0131 \\
B8-2S $^{\mathrm{y}}$ & Wicomico & Maryland & 2 & $\mathrm{C}$ & 0131 \\
B7-9S $^{\mathrm{y}}$ & Wicomico & Maryland & 2 & $\mathrm{C}$ & 0131 \\
$660 \mathrm{~A}^{\mathrm{z}}$ & Wicomico & Maryland & 1 & $\mathrm{~A}$ & 0134 \\
\hline
\end{tabular}

${ }^{\text {w }}$ Restriction fragment length polymorphisms revealed by probing EcoR1 digest of total DNA with a repetitive element cloned from isolate Pt-1 of $F$. oxysporum f. sp. melonis. Isolates sharing all clearly resolved fragments were given the same letter designation. Pattern A1 was a subtle variant of pattern A (Fig. 2).

$\mathrm{x} \mathrm{VCG}=$ vegetative compatibility group.

y Refer to Appel and Gordon (1).

z Refer to Jacobson and Gordon (6).
$(1,6,7)$. Outside the United States, the greatest VCG diversity has been observed in France, where three VCGs are known to occur. Most of the characterized isolates of F. oxysporum f. sp. melonis from France have been assigned to VCG 0134 (7), as have all isolates in South Africa (W. Schreuder, personal communication). In Israel, two VCGs have been identified (8). These situations are consistent with clonal propagation of one or more strains, which in some cases may be recent introductions.

In New York, we have identified 3 VCGs from a sample of 46 isolates, including VCG 0130, previously known only from California. Moreover, 2 isolates were incompatible with each other and tester strains representing all known VCGs of $F$. oxysporum f. sp. melonis and may therefore be associated with 2 new VCGs. The observed incompatibility is not definitive, however, given the lack of fidelity in intraVCG pairings observed with 2 isolates of VCG 0134. Thus, pairings with additional isolates will be required before erecting new VCGs to accommodate these isolates. Nevertheless, even if the isolates in question can be assigned to a known VCG, the complexity of the pattern of inter-isolate compatibility is further testimony to the diversity in the population of $F$. oxysporum f. sp. melonis in New York State. Similar patterns of inter-isolates pairings were observed among isolates associated with $F$. oxysporum f. sp. melonis VCG 0138 in Israel (8). The diversity observed in the New York population, coupled with the fact that New York was one of the first locations where $F$. oxysporum f. sp. melonis was identified, suggests that more intensive sampling of $F$. oxysporum populations in New York, expanded to include strains not pathogenic to melon, may provide considerable insight into the evolutionary and geographic origins of $F$. oxysporum $\mathrm{f}$. sp. melonis.

\section{ACKNOWLEDGMENTS}

This study was supported by funds allocated by the New York State College of Agriculture and Life Sciences for Hatch Project NYC 153-417. We thank J. Drennan for technical assistance, the melon growers who participated in this study, and E. Rutkowski, D. Young, and D. Riggs of Cornell Cooperative Extension for locating the fields used in this survey.

\section{LITERATURE CITED}

1. Appel, D. J., and Gordon, T. R. 1994. Local and regional variation in populations of Fusarium oxysporum from agricultural field soils. Phytopathology 84:786-791.

2. Correll, J. C., Puhalla, J. E., and Schneider, R. W. 1986. Identification of Fusarium oxysporum f. sp. apii on the basis of colony size, virulence, and vegetative compatibility. Phytopathology 76:396-400.

3. Dutky, E. M., Kantzes, J. E., Brooks, A. D., and Kantzes, J. G. 1986. A new race of Fusarium oxysporum f. sp. melonis causing wilt of muskmelons in Maryland. (Abstr.) Phytopathology 76:563.

4. Gordon, T. R., Okamoto, D. and Jacobson, D. J. 1989. Colonization of muskmelon and non- 
susceptible crops by Fusarium oxysporum f. sp. melonis and other species of Fusarium. Phytopathology 79:1095-1100.

5. Gordon, T. R., and Okamoto, D. 1991. Vegetative compatibility groupings in a local population of Fusarium oxysporum. Can J. Bot. 69:168-172.

6. Jacobson, D. J., and Gordon, T. R. 1988. Vegetative compatibility and self-incompatibility within Fusarium oxysporum f. sp. melonis. Phytopathology 78:668-672.

7. Jacobson, D. J. and Gordon, T. R. 1990. Further investigations of vegetative compatibility within Fusarium oxysporum f. sp. melonis. Can. J. Bot. 68:1245-1248.

8. Katan, T., Katan, J., Gordon, T. R., and Pozniak, D. 1994. Physiologic races and vegetative compatibility groups of Fusarium oxysporum f. sp. melonis in Israel. Phytopathology 84:153-157.

9. Kim, D. H., Martyn, R. D., and Magill, C. W. 1993. Mitochondrial DNA (mtdna)-relatedness among formae speciales of Fusarium oxysporum in the Cucurbitaceae. Phytopathology 83:91-97.

10. Komada, H. 1975. Development of a selective medium for quantitative isolation of Fusarium oxysporum from natural soil. Rev. Plant Prot. Res. 8:114-124.

11. Latin, R. X. 1989. Fusarium wilt resistance in muskmelon and watermelon varieties. Purdue University Plant Disease Control Ext. Sheet BP-19.

12. Little, T. M., and Hills, F. J. 1978. Agricultural Experimentation. John Wiley \& Sons, New York.

13. Martyn, R. D., Barnes, W. W., and Amador, J. 1987. Fusarium wilt (F. oxysporum f. sp. melonis race 0) of muskmelon in Texas. Plant Dis. 71:469.

14. Martyn, R. D., and Gordon, T. R. 1996. Fusarium wilt of melon. Pages 14-15 in: Compendium of Cucurbit Diseases. T. A. Zitter, D. L. Hopkins, and C. E. Thomas, eds. American Phytopathological Society, St. Paul, $\mathrm{MN}$.

15. Nelson, P. E. Toussoun, T. A., and Marasas, W. F. O. 1983. Fusarium Species: An Illustrated Manual for Identification. Pennsylvania State University Press, University Park.

16. Ng, T. J., and Kantzes, J. G. 1991. Field screening of melon cultigens for multiple race resistance to Fusarium oxysporum f. sp. melonis. Cucurbit Genetics Coop. 14:55.

17. Puhalla, J. E. 1985. Classification of strains of Fusarium oxysporum on the basis of vegetative compatibility. Can. J. Bot. 63:179-183.

18. Risser, G., Banihashemi, Z., and Davis, D. W. 1976. A proposed nomenclature of Fusarium oxysporum f. sp. melonis races and resistance genes in Cucumis melo. Phytopathology 66:1105-1106.

19. Schroeder, D. T., Gordon, T. R., Okamoto, D. Zuniga, T. L., and Zitter, T. A. 1995. VCG and DNA fingerprint data suggest that Fusarium oxysporum $\mathrm{f}$. $\mathrm{sp}$. melonis race 1 has recently been introduced into New York State. Phytopathology 85:1173

20. Schroeder, D. T, and Gordon, T. R. 1994. An assessment of the relatedness of subpopulations within Fusarium oxysporum f. sp. melonis based on DNA fingerprinting. Phytopathology 83:1346-1347.

21. Zink, F. W. 1992. Genetics of resistance to Fusarium oxysporum f. sp. melonis races 0 and 2 in muskmelon cultivars Honey Dew, Iroquois, and Delicious 51. Plant Dis. 76:162 166.

22. Zink, F. W., and Gubler, W. D. 1985. Inheritance of resistance in muskmelon to Fusarium wilt. J. Am. Soc. Hortic. Sci. 110:600-604.

23. Zuniga, T. L., and Zitter, T. A. 1993. A new race of Fusarium oxysporum f. sp. melonis causing wilt of muskmelon in New York. (Abstr.) Phytopathology 83:1344.

24. Zuniga, T. L., Zitter, T. A., and Gordon, T. R. 1995. Distribution and characterization of Fusarium oxysporum f. sp. melonis from soil samples collected in melon fields in New York. (Abstr.) Phytopathology 85:384. 